\title{
Pasang Surut Surabaya Selama Terjadi El-Nino
}

\author{
Iva Ayu Rinjani dan Bangun Muljo Sukojo \\ Jurusan Teknik Geomatika, Fakultas Teknik Sipil dan Perencanaan, Institut Teknologi Sepuluh Nopember (ITS) \\ Jl. Arief Rahman Hakim, Surabaya 60111 Indonesia \\ e-mail: bangunms@gmail.com
}

\begin{abstract}
Abstrak - Pengaruh fenomena El Nino juga dapat dipelajari dan dianalisis menggunakan data fluktuasi pasang surut di permukaan laut. Pasang surut adalah naik turunnya permukaan laut disebabkan oleh kombinasi dari gaya gravitasi bulan, matahari dan Bumi. Selain itu, perubahan suasana seperti perubahan tekanan, angin dan suhu akan mempengaruhi pola pasang surut dan aktivitas pasang surut. Hasil kajian menunjukan penurunan MSL terjadi di Perairan Surabaya mengikuti persamaan linier dengan persamaan $Y=114.1-0.3782 x$ $\left(R^{2}=20,69 \%\right)$ dengan penurunan MSL sebesar 4,347 cm sepanjang tahun 2014-2015.
\end{abstract}

Kata Kunci- El Nino, MSL (Mean Sea Level), SPL (suhu permukaan laut), Surabaya

\section{PENDAHULUAN}

$\mathrm{E}$ L Nino adalah suatu gejala penyimpangan kondisi laut yang ditandai dengan meningkatnya suhu permukaan laut (Sea Surface Temperature-SST) di Samudra Pasifik sekitar Ekuator (Equatorial pacific), khususnya di bagian tengah dan timur (sekitar pantai Peru). Karena lautan dan atmosfer adalah dua sistem yang saling terhubung, maka penyimpangan kondisi laut ini menyebabkan terjadinya penyimpangan pada kondisi atmosfer yang pada akhirnya berakibat pada terjadinya penyimpangan [1].

Dalam kondisi iklim normal, suhu permukaan laut di sekitar Indonesia (Pasifik bagian barat disekitar ekuator) umumnya hangat dan karenanya proses penguapan mudah terjadi dan awan-awan hujan mudah terbentuk. Namun ketika fenomena $E l$ Nino terjadi, saat suhu permukaan laut di Pasifik Equator bagian tengah dan timur menghangat, justru perairan sekitar Indonesia umumnya mengalami penurunan suhu (menyimpang dari biasanya). Badan Meteorologi, Klimatologi, dan Geofisika (BMKG) menyatakan fenomena $\mathrm{El}$ Nino diprediksi akan menguat mulai Agustus hingga Desember 2015. Tren penguatan El Nino 2015 ini ditunjukkan oleh kenaikan indeks El Nino Southern Oscillation (ENSO) dari 1,6 pada Juni menjadi 2,2 pada Desember 2015 [2]. Panjangnya musim kemarau di berbagai tempat di Indonesia, terutama di sebelah selatan khatulistiwa diduga merupakan dampak dari fenomena El Nino yang mencapai level sedang. Karena tekanan atmosfer dan suhu laut berkaitan erat, indeks atmosfer disebut Southern Oscillation Index (SOI) digunakan untuk mengukur respon atmosfer. Indeks tersebut dihitung dari perbedaan tekanan udara berfluktuasi bulanan antara Tahiti dan Darwin. SOI telah banyak digunakan untuk mengukur intensitas El Nino seperti Kiladis dan Loon (1988) menggunakan SOI untuk mengukur terjadinya El Nino untuk Samudera Pasifik Timur. Selanjutnya,
SOI juga digunakan dalam memantau kegiatan El Nino dengan nilai-nilai SOI. Melalui nilai-nilai SOI, dapat menentukan puncak dan lemah dari El Nino terjadinya [3].

Pengaruh fenomena ini juga dapat dipelajari dan dianalisis menggunakan data fluktuasi pasang surut di permukaan laut. Pasang surut adalah naik turunnya permukaan laut disebabkan oleh kombinasi dari gaya gravitasi bulan, matahari dan Bumi. Selain itu, perubahan suasana seperti perubahan tekanan, angin dan suhu akan mempengaruhi pola pasang surut dan aktivitas pasang surut. Misalnya, sirkulasi angin mempengaruhi terjadinya gelombang laut dan arus laut. Tekanan atmosfer dan curah hujan juga mempengaruhi fluktuasi dari permukaan laut. Pengetahuan parameter meteorologi dan variabel oceanografi di perairan Indonesia diperlukan untuk memahami karakteristik dinamis dan pasang tinggi, terutama selama dan pemanasan global.

Pembentukan jaringan pasang surut di Indonesia adalah untuk mengamati pasang terus menerus. Ini termasuk pembentukan permukaan laut nilai rata-rata untuk setiap stasiun. Selain itu, pengamatan pasang surut digunakan untuk analisis pasang surut untuk menentukan konstituen pasang surut dan digunakan untuk prediksi. Selain itu, jaringan pasang memainkan peran penting dalam menentukan karakteristik atau perilaku sepanjang pesisir terutama selama perubahan iklim mendadak seperti fenomena El Nino, yang Monsoon Timur Laut, Barat Laut Monsoon dan Tsunami [4].

Menurut Crawford dkk, [3] pengaruh kekinian dan anomali seperti El Nino mempengaruhi akurasi konstanta pasang surut. Pengaruh tertinggi yang tercatat dikonstanta periode panjang pasang surut adalah karena pengaruh El Nino. Oleh karena itu, penelitian ini dilakukan untuk mengidentifikasi variasi harmonik pasang surut selama terjadi El Nino. Data yang digunakan adalah data pengamatan pasang surut in situ, data suhu permukaan laut, dan data SOI.

\section{METODOLOGI PENELITIAN}

\section{A. Lokasi Penelitian}

Lokasi yang dipilih untuk melakukan penelitian ini adalah di perairan Surabaya, Indonesia. Batasan wilayah penelitian adalah data dari stasiun pasang surut terletak di area Pelabuhan Tanjung Perak Surabaya dengan lokasi koordinat Lintang $07^{\circ} 12^{\prime} 0.2^{\prime \prime}$ LS dan Bujur 112 44’26,7” BT. 


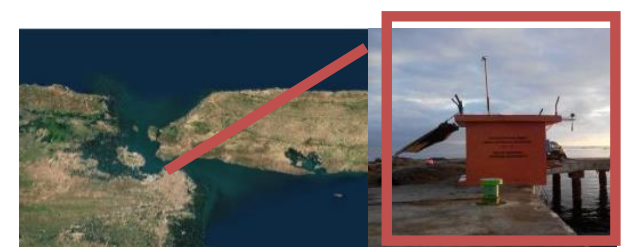

Gambar 1 Perairan Surabaya dan Stasiun pasut Pelabuhan Tanjung Perak Sumber: Badan Informasi Geospasial, 2015

\section{B. Data yang Digunakan}

Penelitian ini menggunakan data pasang surut daerah Pelabuhan Tanjung Perak tahun 2014-2015. Data ini didapatkan dari Badan Informasi Geospasial. Selain data pasang surut, data suhu permukaan laut didapatkan dari citra Aqua MODIS Sea Surface Temperature level 3 tahun 20142015. Data citra ini dapat diunduh di http://oceancolor.gsfc.nasa.gov/ . Sedangkan untuk data suhu pembanding bisa diunduh di http://ecmwf.int/. Data pasang surut ini nantinya digunakan untuk menghitung MSL (Mean Sea Level) dan Harmonik pasang surut, sedangkan suhu akan digunakan untuk menunjukkan hubungan dengan fenomena $\mathrm{El}$ Nino.

\section{Pengolahan Data}

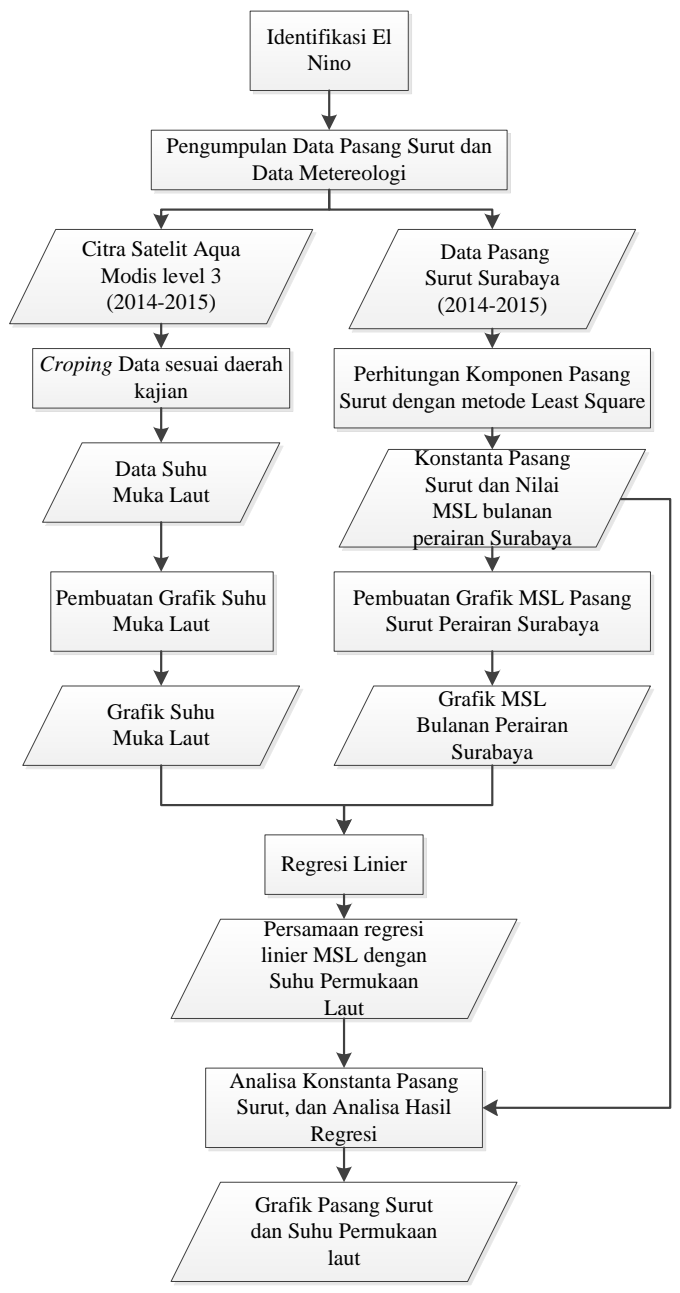

Gambar 2 Diagram Alir Penelitian

Penjelasan dari diagram alir penelitian ini adalah:

1) Pengolahan data pasang surut dengan metode least square.
Dalam proses pengolahan data pasang surut meliputi tahapan seperti perhitungan komponen pasang surut dengan metode least square dengan persamaan [5]:

$$
h t_{i}=Z_{0}+\sum_{1}^{n} A_{n} \cos \left(\varpi_{n} t_{i}\right)-\sum_{1}^{n} B_{n} \sin \left(\varpi_{n} t_{i}\right)
$$

di mana $A n$ dan $B n$ merupakan konstanta harmonik dan $\omega_{\mathrm{n}}$ adalah jumlah komponen pasut serta $t i$ pengamatan pasut jam ke- $n$. Nilai $\omega$ merupakan konstanta periode komponenkomponen pasang surut.

Berdasarkan persamaan akan didapatkan linierisasi berupa matriks desain $A$ berdasarkan persamaan (1) dengan rumusan sebagai berikut:

$$
\begin{aligned}
& \mathrm{Htn}=\mathrm{So} \\
& +A 1 . \operatorname{Cos}(\omega 1 \mathrm{tn})-B 1 . \operatorname{Sin}(\omega 1 \mathrm{tn}) \\
& +A 2 . \operatorname{Cos}(\omega 2 \mathrm{tn})-B 2 . \operatorname{Sin}(\omega 2 \mathrm{tn}) \\
& +A 3 \cdot \operatorname{Cos}(\omega 3 \mathrm{tn})-B 3 . \operatorname{Sin}(\omega 3 \mathrm{tn}) \\
& +A 4 \cdot \operatorname{Cos}(\omega 4 \mathrm{tn})-B 4 . \operatorname{Sin}(\omega 4 \mathrm{tn}) \\
& +A 5 . \operatorname{Cos}(\omega 5 \mathrm{tn})-B 5 . \operatorname{Sin}(\omega 5 \mathrm{tn}) \\
& +A 6 . \operatorname{Cos}(\omega 6 \mathrm{tn})-B 6 . \operatorname{Sin}(\omega 6 \mathrm{tn}) \\
& +A 7 . \operatorname{Cos}(\omega 7 \mathrm{tn})-B 7 . \operatorname{Sin}(\omega 7 \mathrm{tn}) \\
& +A 8 . \operatorname{Cos}(\omega 8 \mathrm{tn})-B 8 . \operatorname{Sin}(\omega 8 \mathrm{tn}) \\
& +A 9 \cdot \operatorname{Cos}(\omega 9 \mathrm{tn})-B 9 \cdot \operatorname{Sin}(\omega 9 \mathrm{tn})
\end{aligned}
$$

Dalam memperoleh nilai $A n$ dan $B n$ digunakan perhitungan berdasarkan hasil matriks parameter $\mathrm{X}$ dengan rumusan:

$$
[X]=\left[A^{T} \cdot A\right]^{-1} A^{T} \cdot L
$$

Sehingga diperoleh amplitude nilai Mean Sea Level So sebagai nilai Mean Sea Level yang merupakan salah satu komponen parameter matriks X( Nilai bobot diasumsikan 1). Nilai So merupakan nilai Mean Sea Level yang kemudian akan dicari nilai kenaikannya.

2) Mengekstrak data suhu permukaan laut dari citra satelit

Aqua MODIS level 3 dari tahun 2014-2015.

3) Pembentukan grafik muka air laut dan grafik suhu permukaan laut.

4) Regresi Linier

Regresi linier merupakan bentuk persamaan garis lurus dari suatu hubungan variabel bebas $\mathrm{x}$ dan variabel tak bebas $\mathrm{y}$ dengan bentuk persamaan:

$$
\mathrm{y}=a_{0}+a_{1} \mathrm{x}
$$

dimana $a_{0}$ dan $a_{1}$ adalah koefisisen-koefisien yang masingmasing mewakili perpotongan (intercept) dan kemiringan (slope) untuk persamaan umum regresi linier). Dalam hal ini variabel $\mathrm{x}$ dan y berupa variabel suhu permukaan laut dan nilai MSL sehingga hasil yang didapatkan berupa persamaan regresi linier.

\section{HASIL DAN ANALISA}

\section{A. Identifikasi El Nino}

Nilai data SOI (standart Oscillation Indeks) merupakan indek untuk mengetahui seberapa kuat fenomena El-Nino, 
untuk stasiun pengamatan Nino 3.4 tahun 2014-2015 seperti terlihat pada Tabel 1 berikut ini:

Tabel 1

Nilai SOI Stasiun Nino 3.4

\begin{tabular}{lcc}
\hline \hline \multirow{2}{*}{ Bulan } & \multicolumn{2}{c}{ Tahun } \\
\cline { 2 - 3 } & 2014 & 2015 \\
\hline Januari & $-0,5$ & 0,5 \\
Februari & $-0,6$ & 0,4 \\
Maret & $-0,4$ & 0,5 \\
April & $-0,2$ & 0,7 \\
Mei & 0 & 0,9 \\
Juni & 0 & 1,0 \\
Juli & 0 & 1,2 \\
Agustus & 0 & 1,5 \\
September & 0,2 & 1,8 \\
Oktober & 0,4 & 2,1 \\
November & 0,6 & 2,2 \\
Desember & 0,6 & 2,3 \\
\hline \hline
\end{tabular}

Dari data pada Tabel 1 nilai SOI pada bulan April Desember 2015 lebih besar dari 0,5. Hal ini dapat diidentifikasi bahwa fenomena El Nino mulai menguat [6] .

Berikut ini merupakan Gambar 3 tentang nilai SOI yang terjadi pada tahun 2014-2015:

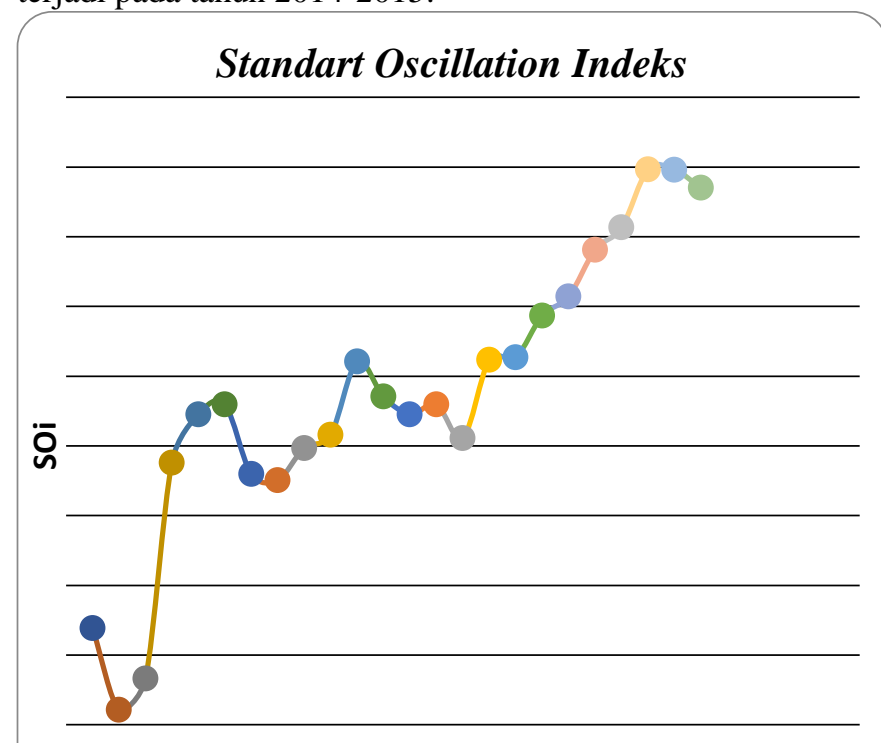

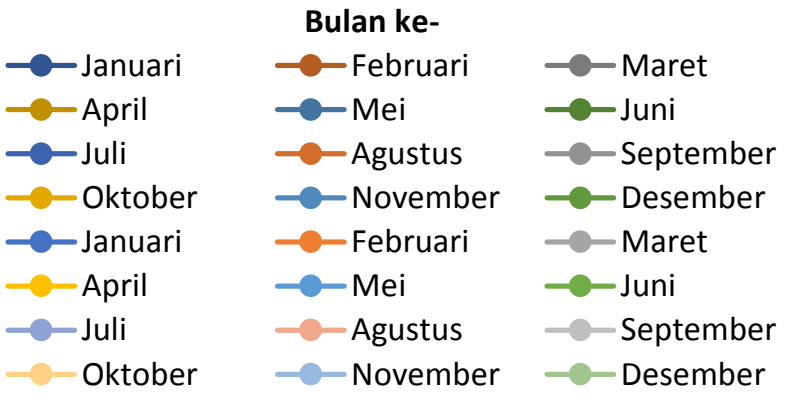

Gambar 3 Grafik tren SOI tahun 2014-2015

Selanjutnya dilakukan pengolahan data suhu yang diekstrak dari citra aqua modis sea surface temperature level 3 dengan menggunakan perangkat lunak seadas seperti yang diperlihatkan pada tabel berikut ini:

Tabel 2

Nilai suhu AQUA MODIS Sea Surface Temperature Level 3

\begin{tabular}{lll}
\hline \hline \multirow{2}{*}{ Bulan } & \multicolumn{2}{c}{ Tahun } \\
\cline { 2 - 3 } & 2014 & 2015 \\
\hline Januari & 29,2 & 30,5 \\
Februari & 29,9 & 30,9 \\
Maret & 31,3 & 30,8 \\
April & 29,2 & 31,6 \\
Mei & 30,7 & 29,7 \\
Juni & 30,2 & 29,4 \\
Juli & 29,4 & 28,3 \\
Agustus & 29,2 & 28,6 \\
September & 28,9 & 29,1 \\
Oktober & 30,3 & 29,2 \\
November & 31,1 & 33,2 \\
Desember & 34,2 & 31,3 \\
\hline \hline
\end{tabular}

Dapat dilihat saat terjadi El Nino suhu permukaan laut di perairan Surabaya mengalami penurunan suhu dari rata-rata suhu normalnya yaitu lebih besar dari $0,5^{\circ} \mathrm{C}$ [6]. Selanjutnya dari data suhu tersebut dijadikan grafik.

Adapun pembuatan grafik dilakukan untuk melihat secara grafis perubahan suhu permukaan laut bulanan.. Berikut ini pada Gambar 4 grafik suhu permukaan laut (SPL) Surabaya:

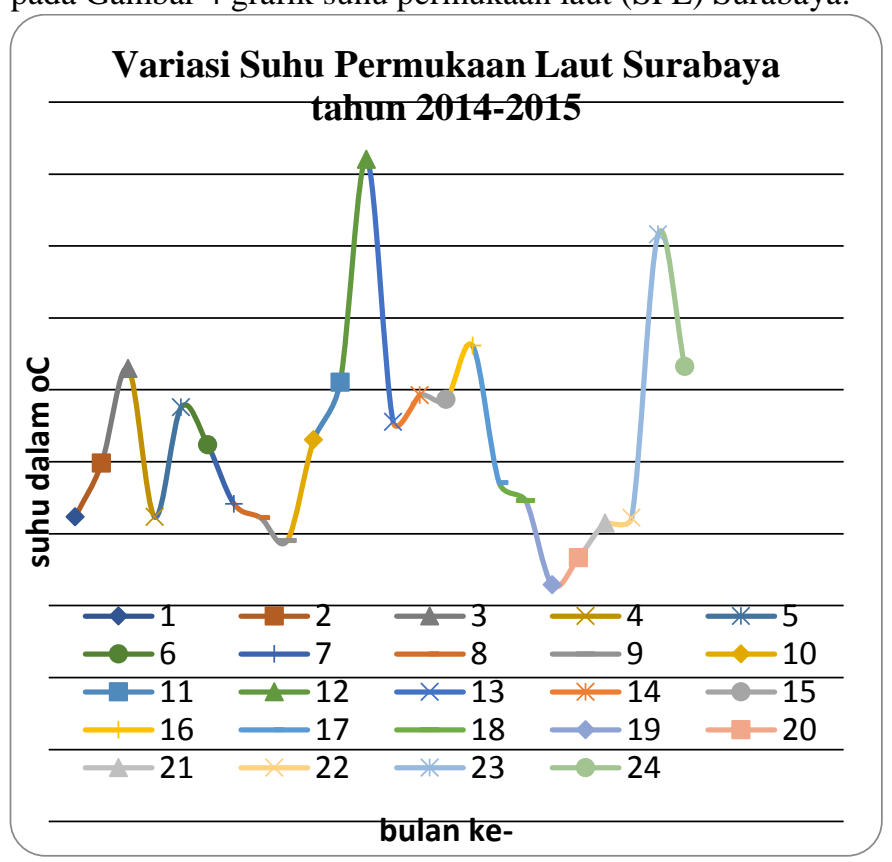

Gambar 4 Grafik suhu permukaan laut perairan Surabaya tahun 2014-2015

Grafik nilai SPL Surabaya tahun 2014-2015 menunjukkan bahwa nilai SPL Surabaya fluktuatif. Hal ini dapat dilihat pada nilai SPL tertinggi sebesar $34,2^{\circ} \mathrm{C}, 33,2^{\circ} \mathrm{C}$, dan $31,6^{\circ} \mathrm{C}$ pada Desember 2014, November 2015, dan April 2015. Sedangkan nilai SPL terendah sebesar $28,3^{\circ} \mathrm{C}, 28,7^{\circ} \mathrm{C}$ dan $28,9^{\circ} \mathrm{C}$ pada Juli 2015, Agustus 2015, dan September 2014.

\section{B. Variasi Muka Air Laut Rata-rata}

Hasil pengolahan data pasang surut berupa nilai muka air laut rata-rata (MSL) untuk lokasi Surabaya tahun 2014-2015 seperti terlihat pada Tabel 3 berikut ini:

Tabel 3

Nilai MSL Surabaya (dalam satuan $\mathrm{cm}$ )

\begin{tabular}{lcc}
\hline \hline \multicolumn{1}{c}{ Bulan/ Tahun } & 2014 & 2015 \\
\hline Januari & 122,09 & 117,79 \\
Februari & 105,12 & 105,39
\end{tabular}




\begin{tabular}{lll} 
Maret & 104,65 & 106,54 \\
April & 109,16 & 110,66 \\
Mei & 117,80 & 115,90 \\
Juni & 117,30 & 112,15 \\
Juli & 114,99 & 108,09 \\
Agustus & 110,40 & 105,34 \\
September & 104,25 & 101,15 \\
Oktober & 103,87 & 101,85 \\
November & 108,13 & 103,92 \\
Desember & 113,69 & 103,79 \\
\hline \hline
\end{tabular}

Nilai Mean Sea Level untuk lokasi pengamatan Surabaya dari tahun 2014 hingga 2015 bervariasi. Nilai MSL terendah 101,15 cm di atas nol rambu pada September 2015 dan nilai MSL tertinggi 122,09 $\mathrm{cm}$ di atas nol rambu pada Januari 2014. Rentang variasi nilai MSL terendah-tertinggi sebesar 20,94 cm.

Kemudian dari nilai muka air laut (MSL), selanjutnya data hasil pengolahan dijadikan grafik dengan perangkat lunak Microsoft excel. Adapun pembuatan grafik dilakukan untuk melihat secara grafis perubahan kedudukan muka air laut. Berikut ini pada Gambar 5 grafik Mean Sea Level (MSL) Surabaya:

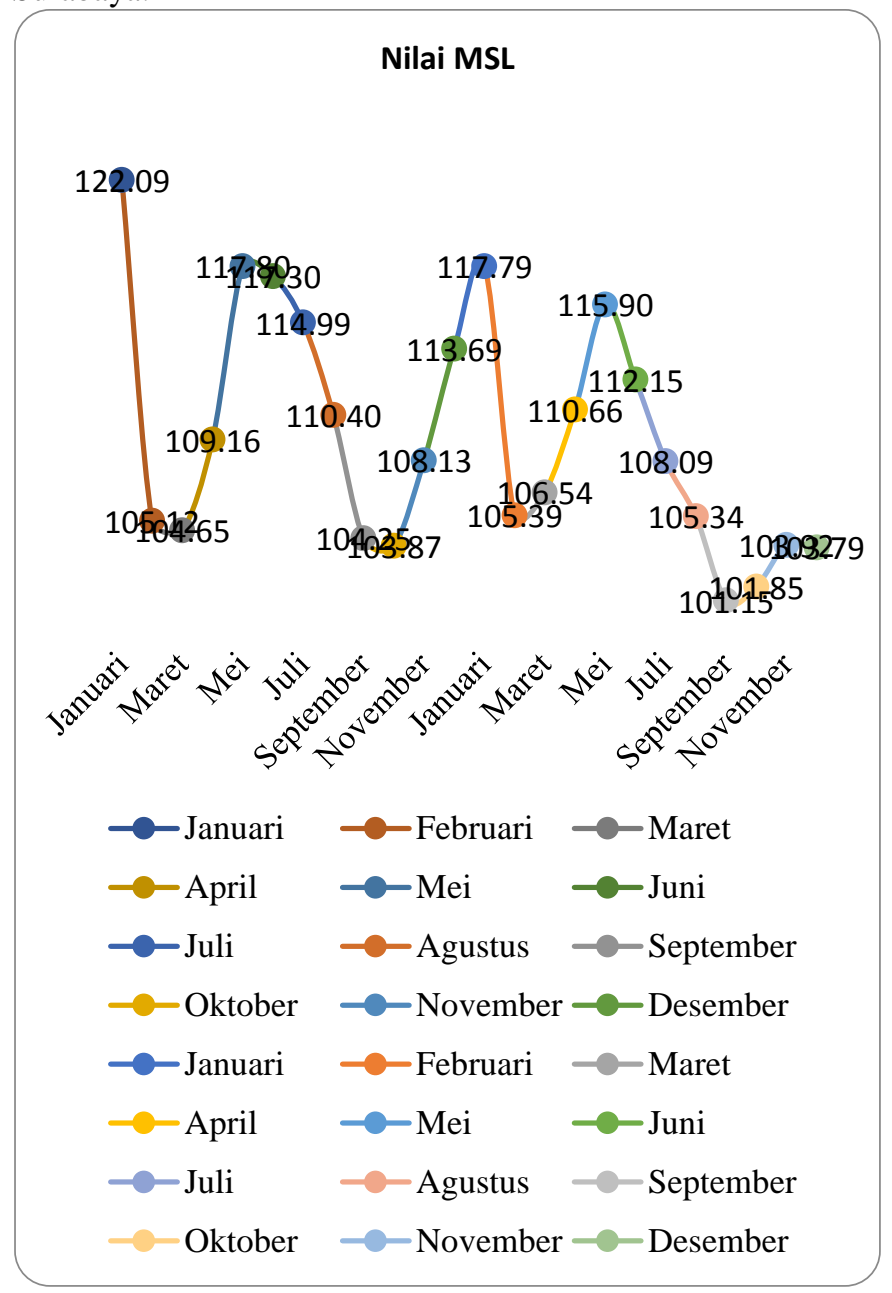

Gambar 5 Grafik MSL perairan Surabaya tahun 2014-2015 (dalam satuan cm)

Grafik nilai MSL Surabaya tahun 2014-2015 menunjukkan bahwa nilai MSL Surabaya fluktuatif. Hal ini dapat dilihat pada nilai MSL tertinggi sebesar 122,09 cm, 117,80 cm, dan 117,79 cm pada Januari 2014, Mei 2014, dan Januari 2015. Sedangkan nilai MSL terendah sebesar $101,15 \mathrm{~cm}, 101,85 \mathrm{~cm}$ dan 103,79 cm pada September 2015, Oktober 2015, dan Desember 2015.

C. Hasil Scatterplot Mean Sea Level (MSL) dan Hubungan suhu permukaan laut dengan MSL

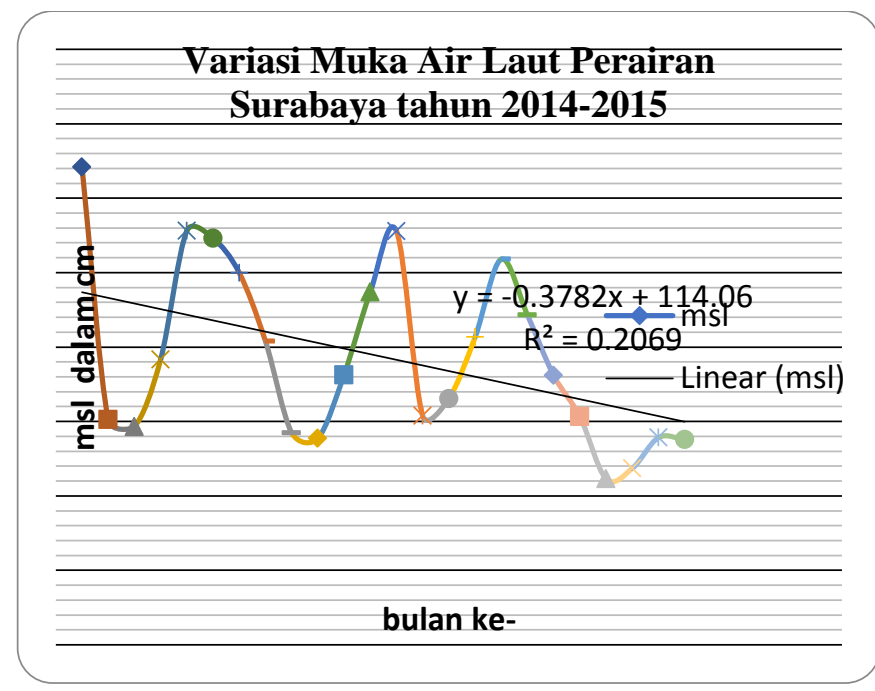

Gambar 6 Tren MSL Surabaya

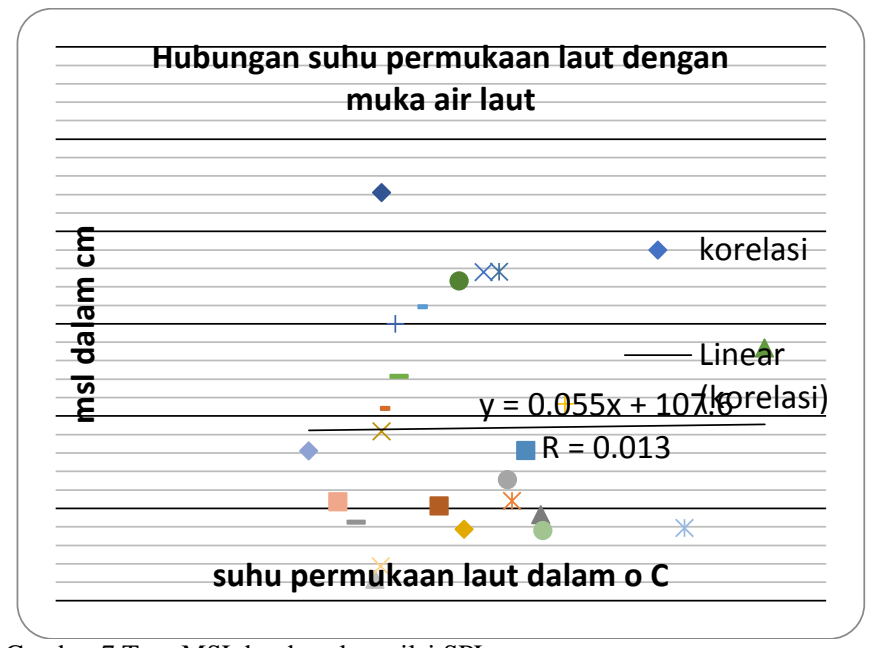

Gambar 7 Tren MSL berdasarkan nilai SPL

\section{Analisa Hasil Regresi Linier Variasi Muka Air Laut}

Diketahui persamaan regresi linier untuk tren Surabaya adalah $\mathrm{y}=114,1-0,3782 \mathrm{x}$. sesuai dengan persamaan tersebut nilai $\mathrm{x}$ dapat disubtitusikan dengan nilai bulan minimal dan bulan maksimal dari data yang ada. Dalam hal ini variabel $\mathrm{x}$ Surabaya minimal 1 bulan dan maksimal 24 bulan. Kemudian disubtitusikan nilai $\mathrm{x}=1$ dan $\mathrm{x}=24$ kedalam persamaaan sehingga diperoleh:

$\mathrm{X}=1$ bulan $\rightarrow$ y awal $=113,722 \mathrm{~cm}$ dan $\mathrm{X}=24$ bulan $\rightarrow$ y akhir $=105,028 \mathrm{~cm}$

Untuk mencari nilai tren kenaikan pertahun maka dilakukan perhitungan seperti rumusan dibawah ini:

Tren $=(\mathrm{Y}$ akhir-Yawal $) /$ jumlah tahun 
Sehingga didapatkan nilai tren MSL Surabaya $=-4,347$ $\mathrm{cm} /$ tahun.

Pada pengukuran tingkat kesesuaian model regresi yang digunakan adalah dengan melihat $\mathrm{R}$ Square (2) hasil permodelan dengan harga pendekatan R2 adalah skala 0-1. Artinya semakin mendekati 1 maka nilai pemodelan sesuai. Berdasarkan regresi linier didapatkan hasil penurunan MSL Surabaya sebesar 4,347 cm per tahun dan R2 mencapai 0,2069 atau $20,69 \%$. Permodelan ini belum mendekati nilai 1 artinya permodelan ini memiliki kesesuain mencapai 0,2069. Hal ini disebabkan banyak data pengamatan pasang surut yang kosong, sehingga dilakukan interpolasi, sehingga hasil MSL dan permodelan yang digunakan belum maksimal.

\section{E. Analisa Hasil Regresi Linier antara SPL dengan Muka Air} Laut Rata-rata.

Diketahui persamaan regresi linier untuk hubungan MSL dengan SPL adalah $y=107,7+0,055 x$. sesuai dengan persamaan tersebut nilai $x$ dapat disubtitusikan dengan nilai bulan minimal dan bulan maksimal dari data yang ada.

Untuk mengukur tingkat kesesuaian model regresi yang digunakan adalah dengan melihat $R$ Square $\left(R^{2}\right)$ hasil permodelan dengan harga pendekatan $\mathrm{R}^{2}$ adalah skala 0-1. Artinya semakin mendekati 1 maka nilai pemodelan sesuai. Berdasarkan regresi linier didapatkan hasil tren MSL berdasarkan SPL Surabaya sebesar $0,16 \mathrm{~cm}$ per tahun dan R2 mencapai 0.013 atau 1,3\%. Permodelan ini belum mendekati nilai 1 artinya permodelan ini memiliki kesesuain mencapai 0,013 . Hal ini disebabkan suhu hanya sedikit mempengaruhi perubahan muka air laut, serta masih dibutuhkan variabel lain yang berhubungan dan memiliki pengaruh yang lebih kuat seperti curah hujan dan tekanan udara. Sehingga hasil permodelan yang digunakan belum maksimal.

Akan tetapi dari data variasi muka air laut perairan Surabaya yang tersedia, terdapat satu waktu yang menandai terjadinya $E l$ Nino. Seperti yang dilihat pada Gambar 4, variasi muka air laut pada bulan Mei hingga Desember tahun 2015 menandakan kecenderungan penurunan yang cukup signifikan.

\section{KESIMPULAN}

Adapun beberapa hal yang dapat disimpulkan dari penelitian ini adalah:

1) Hasil nilai muka air laut rata-rata perairan Surabaya tertinggi sebesar 122,09 cm pada bulan Januari 2014 dan nilai terrendah sebesar 103,79 $\mathrm{cm}$ pada bulan Desember tahun 2015 seperti gambar 5. Hasil nilai suhu permukaan laut perairan Surabaya tertinggi $34,20{ }^{\circ} \mathrm{C}$ dan nilai terrendah sebesar $28,28^{\circ} \mathrm{C}$

2) Penurunan MSL di Perairan Surabaya selama terjadi $E l$ Nino mengikuti persamaan linier dengan persamaan $\mathrm{Y}=$ 114.1-0.3782x $\left(\mathrm{R}^{2}=0,2069\right) \quad$ dengan penurunan MSL sebesar 4,347 cm per tahun. Hubungan tren MSL dengan SPL di Perairan Surabaya mengikuti persamaan linier dengan persamaan $Y=107,7+0,055 x(R=0,013)$.

3) Berdasarkan penelitian ini dapat diketahui bahwa pada saat mulai terjadi El Nino variasi muka air laut perairan Surabaya mengalami penurunan. Bila dilakukan penelitian yang lebih lanjut tentang hubungan pasang surut perairan Indonesia dengan fenomena El Nino sebaiknya ditambahkan komponen-komponen metereologi lainnya, seperti curah hujan dan tekanan udara.

\section{DAFTAR PUSTAKA}

[1] Supari, M. (2015). Sejarah Dampak El Nino Indonesia. Badan Meteorologi, Klimatologi dan Geofisika.

[2] Linggasari, Y. (2015). El Nino Menguat, Kemarau Diperkirakan Hingga November. CNN Indonesia.

[3] Abdullah, M. H., Mahmud, M. R., \& Amat, N. A. (2015). Variations of Sea Level and Tidal Behavior during El Nino/ La Nina: An Example of Malaysian Coastline. Junal Teknologi , 107-118.

[4] Badan Informasi Geospasial. (2014). Peta Inageoportal. Http://www.tanahair.indonesia.go.id. (diakses tanggal 26 Desember, 2015)

[5] Ongkosongo. 1989. Pasang Surut. Jakarta: LIPI.

[6] Riyadi. (2013). Pengamatan Pasang Surut Air Laut di Pelabuhan Bitung Sebagai Prediksi Awal Terjadi El Nino dan La Nina. Kasie Data dan Informasi Stasiun Geofisika Manado. 